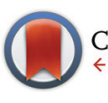

CrossMark \&lick for updates

Cite this: Polym. Chem., 2015, 6 , 4612

Received 27th March 2015, Accepted 1st May 2015

DOI: $10.1039 / c 5 p y 00461 f$

www.rsc.org/polymers

\title{
Evaluating chemical ligation techniques for the synthesis of block copolypeptides, polypeptoids and block copolypept(o)ides: a comparative study $\dagger$
}

\begin{abstract}
Kristina Klinker, ${ }^{a}$ Regina Holm, ${ }^{\text {b }}$ Philipp Heller ${ }^{a}$ and Matthias Barz ${ }^{\star b}$
In this work, we describe the synthesis of block copolypeptides, polypeptoids and block copolypept(o)ides by chemical ligation techniques. Polysarcosine (PSar), poly( $N$ - $\varepsilon$-trifluoroacetyl-L-lysine) (PLys(TFA)) and poly $(\gamma$-benzyl-L-glutamate) (PGlu(OBzl)) homopolymers of different polarities and end group functionalities but with similar average degrees of polymerization $\left(X_{n}=50\right.$ and 100) could be obtained by ring opening polymerization (ROP) of $\alpha$-amino acid $N$-carboxyanhydrides (NCA) and postpolymerization modification reactions. In the next step, these polymers were applied to copper(I)-catalyzed azide-alkyne coupling (CUAAC), strain-promoted azide-alkyne coupling (SPAAC) and native chemical ligation (NCL). Our results suggest that all the employed ligation techniques can be used for the synthesis of block copolypeptides, polypeptoids and block copolypept(o)ides. SPAAC displayed, for most conditions, the highest ligation efficiencies (up to $86 \%$ ) and, from a practical point of view, is the most feasible method. NCL, however, performed very well for short hydrophilic polymers (up to $88 \%$ ) and is favourable for the ligation of peptides from solid phase peptide synthesis (SPPS) to polysarcosine. As a proof of principle, we report a protocol for an efficient NCL coupling of polysarcosine to the T-cell receptor core peptide (TCR CP), which is known to inhibit IL-2 production in antigen-stimulated T cells and, therefore, to suppress inflammation. In a comparative study, the ligation method, which directly relates to the chemical nature of the ligation site, neither influenced cytotoxicity nor complement activation. To conclude, chemical ligation techniques represent a complementary synthetic approach to the well-established sequential ring opening polymerization of NCAs.
\end{abstract}

\section{Introduction}

Synthetic polypeptides still see a steady increase of interest as synthetic materials for application in nanomedicine. The polypeptidic copolymer Copaxone ${ }^{\circledR}$ was among the 20 best selling drugs in 2013. Although the polymerization of $\alpha$-amino acid $N$ carboxyanhydrides (NCAs) was reported at the beginning of the last century by Hermann Leuchs, it took until the late 90s for first reports on controlled polymerization to be published.

\footnotetext{
${ }^{a}$ Graduate School Materials Science in Mainz, Staudinger Weg 9, 55128 Mainz, Germany

${ }^{b}$ Institute of Organic Chemistry, Johannes Gutenberg-Universität Mainz, Duesbergweg 10-14, 55128 Mainz, Germany. E-mail: barz@uni-mainz.de; Fax: +49 6131-39-24778; Tel: +49 6131-39-26256

$\dagger$ Electronic supplementary information (ESI) available: ${ }^{1} \mathrm{H}$ NMR spectra of homopolymers, S-benzyl thiosuccinic acid, 3-azido-1-aminopropane, and IR spectra of azide polymers. ${ }^{1} \mathrm{H}$ NMR spectra of ligation products by CuAAC for short chain lengths $\left(X_{\mathrm{n}}=50\right)$. HFIP-GPC elugrams and fits of all the performed ligation experiments (and of the employed homopolymers respectively), and MALDI-TOF spectra for PSar $_{50}$ with all five end group modifications. See DOI: 10.1039/c5py00461f
}

While Deming employed metal complexes for the initiation of the polymerization, ${ }^{1}$ Cheng and coworkers used $N$-trimethylsilyl amines. ${ }^{2}$ Vayaboury et al. reported the use of primary amines as initiators at low temperatures ${ }^{3}$ and Vicent and coworkers controlled the amine activity by ammonium salts with non-nucleophilic counterions. ${ }^{4}$ In addition, Peng et al. have employed rare earth borohydrides as initiators for the ROP of NCAs yielding $\alpha$-hydroxy- $\omega$-aminotelechelic polypeptides. ${ }^{5,6}$ All these aforementioned methods yield well-defined polypeptides.

These polymers - unlike most other biocompatible synthetic polymers - have the potential to combine the hydrolytic stability with in vivo degradability. In the case of enzymatic degradation, polypeptides can decompose into $\alpha$-amino acids, which may be further metabolized in the organism, avoiding design limitations due to renal excretion or storage diseases. ${ }^{7,8}$ For these reasons, polypeptides have become intriguing candidates as materials in drug delivery applications. ${ }^{9}$ Although polymer-protein conjugates have already entered clinical practice, polymeric micelles, polyplexes and nanohydrogels are expected to shape the future of nanomedicine. These systems combine a functional core with a stealth-like corona and are 
formed by electrostatic/entropic or polarity driven self-assembly of block copolymers. While in the first case, the cargo (siRNA, mRNA or pDNA) shapes the properties of the system, the size and shape of the second are mainly determined by the hydrophobic-hydrophilic ratio and the chemical nature of the individual polymer blocks within the amphiphilic block copolymer. $^{10,11}$

Recently, Birke et al. and Heller et al. have introduced polypept(o)ides as a class of functional block copolymers based on the polypeptoid polysarcosine (PSar) and functional polypeptides. ${ }^{12-15}$ PSar - poly( $N$-methyl glycine) - seems to be a particularly interesting alternative to polyethylene glycol (PEG) since it shows very similar physicochemical properties. It is soluble in aqueous solution and in organic solvents, e.g., DMSO or chloroform, and is exclusively a weak hydrogen bond acceptor, which prevents the formation of secondary structures other than random coils. ${ }^{16,17}$ In addition, a similar protein resistance to PEG has been reported. ${ }^{16,18}$ Kimura and coworkers as well as our research group have investigated PSar as a hydrophilic block in amphiphilic block copolymers as an alternative to PEG. ${ }^{19,20}$

Block copolypept(o)ides are readily synthesized by the sequential polymerization of NCAs, where the first block acts as the macroinitiator for the second block. However, chemical ligation techniques are thought to present an important alternative pathway to block copolypept(o)ides whenever a functional block is required, which cannot be derived by NCA polymerization. This can be the case if the second block needs to possess a specific sequence and is, thus, synthesized by solid phase peptide synthesis (SPPS). Also, the second block might not tolerate deprotection conditions that are mandatory for the other. The class of chemical ligation reactions mostly relies on the selective reaction between two (bio)orthogonal groups, which are ideally absent from peptides and proteins (or biomolecules in general). Amongst these are azides, alkynes, tetrazine and many others that have been widely used for different in vitro and in vivo applications. They range from the labeling of biomolecules with fluorescent probes, affinity tags and isotope labels to the synthesis of glycopeptides and biohybrids such as polymer-protein conjugates, cell-surface labeling and the immobilization of proteins. ${ }^{21-24}$

Efficient ligation methods are characterized by a very high selectivity for product formation, easy purification and mild reaction conditions (room temperature and physiological $\mathrm{pH}$ ), which is essential for many proteins in order to maintain their activity. $^{22,25}$

Probably one of the best known chemical ligation techniques is the classical "click" reaction: $\mathrm{Cu}^{\mathrm{I}}$-catalyzed cycloaddition of azides and terminal alkynes (CuAAC) developed by Sharpless ${ }^{26}$ and separately by Meldal and co-workers. ${ }^{27}$ In contrast to Huisgen's 1,3-dipolar cycloaddition, ${ }^{28,29}$ only the 1,4 substituted stereoisomer is obtained under much milder reaction conditions. CuAAC can be conducted in different solvents, including water and buffered saline at physiological $\mathrm{pH}$. To avoid the use of copper(I) as a catalyst, especially with regard to in vivo applications, the strain-promoted alkyne-azide cyclo- addition (SPAAC) has been developed by Bertozzi et al. ${ }^{30}$ The initial idea dates back to discoveries of Wittig and Krebs who reported that cyclooctynes react with azides to form triazoles. ${ }^{30,31}$ For non-substituted cyclooctynes, the reaction rates are relatively slow $\left(0.0012 \mathrm{M}^{-1} \mathrm{~s}^{-1}\right)$, but the attachment of electron-withdrawing groups or additional ring-strain has been shown to significantly improve reaction rates. ${ }^{32}$ Azide-alkyne coupling reactions have been widely used in very different fields, including chemical biology, drug discovery, materials science and polymer science. ${ }^{33-35}$ There are many examples where click chemistry has been successfully employed in the synthesis of nanocarriers for drug delivery. ${ }^{36,37}$

Native chemical ligation (NCL) is another interesting ligation technique since it results in an amide bond at the ligation site instead of an electron-poor aromatic system. The method was developed by Dawson and Kent in the early 90s. ${ }^{38,39}$ Today, it is one of the most effective practical methods for the total synthesis of proteins by using fully unprotected peptide fragments. This is an important aspect when considering the fact that coupling of protected peptide fragments is often limited by the insolubility in aqueous media of longer peptide chains. ${ }^{40}$ It has recently been shown by Dittmann et al. that NCL can be performed in polar aprotic organic solvents like DMF with the addition of a base without racemization, which is potentially very useful for the ligation of hydrophobic peptide segments. ${ }^{41,42}$

While a lot of research has been devoted to different kinds of ligation strategies, a systematic comparison of such methodologies for the synthesis of block copolymers is missing. Here, we report a comparative study of chemical ligation techniques, namely CuAAC, SPAAC and NCL, for the synthesis of block copolypeptides, polypeptoids and block copolypept(o)ides. Polymers used for the individual ligations differ in the chain length, polarity and chemical nature of end groups. We report the optimized conditions for the individual reactions and provide coupling efficiencies. Furthermore, we describe the synthesis and purification of a polysarcosinepeptide conjugate derived by the described methodology, which is of amphiphilic nature. The employed T-cell receptor core peptide (TCR CP) is known to inhibit IL-2 production in antigen-stimulated $\mathrm{T}$ cells. ${ }^{43}$

\section{Experimental section}

\section{Materials and methods}

Solvents were purchased from Sigma Aldrich. THF and $n$ hexane were dried over $\mathrm{Na} / \mathrm{K}$ prior to use. DMF was purchased from Acros (99.8\%, Extra), dried over $\mathrm{BaO}$ and molecular sieves (3/4 $\AA$ ) and fractionally distilled in vacuo. Freshly distilled DMF was stored at $-80{ }^{\circ} \mathrm{C}$ under exclusion of light. Before use, DMF was degassed under vacuum for at least 20 minutes to remove the residual dimethylamine. Acetonitrile was dried over $\mathrm{K}_{2} \mathrm{CO}_{3}$ for $24 \mathrm{~h}$ over molecular sieves ( $3 \AA$ ) for another $24 \mathrm{~h}$ and then distilled. Diphosgene was purchased from Alfa Aesar and used without further purification. Neo- 
pentylamine (TCI Europe), propargylamine (Sigma Aldrich) and triethylamine (TEA) were dried over $\mathrm{NaOH}$ before use and distilled. 4-Mercaptophenylacetic acid (MPAA) and tris(2-carboxyethyl)phosphine hydrochloride (TCEP.HCl) were purchased from Sigma Aldrich and used as received. 3-Chloropropylamine hydrochloride and sodium azide were purchased from Acros. Benzyl mercaptan was purchased from Alfa Aesar. Protected amino acids were bought from ORPEGEN. Dibenzocyclooctyne-amine (DBCO-amine) was bought from Sigma Aldrich and used as purchased. TCR CP (CGLRILLLKV) was custom made by Peptide Specialty Laboratories $\mathrm{GmbH}$. Millipore water was prepared using a MILLI-Q ${ }^{\circledR}$ Reference A+ System. Water was used at a resistivity of $18.2 \mathrm{M} \Omega \mathrm{cm}$ and total organic carbon $<5 \mathrm{ppm} .{ }^{1} \mathrm{H}$ and ${ }^{13} \mathrm{C}$ NMR spectra were recorded on a Bruker AC 300 or AV 400 at room temperature. Spectra were calibrated using the solvent signals $\left(\delta=2.500 \mathrm{ppm}\right.$ for DMSO-d $6, \delta=7.260 \mathrm{ppm}$ for $\left.\mathrm{CDCl}_{3}\right)$. Degrees of polymerization were calculated by comparing the integral of the given initiator peaks either with the integrals of the average of integrals of the benzylic methylene protons and benzylic protons of the protecting group (for PGlu(OBzl)), with the integrals of the $\varepsilon$-protons (for PLys(TFA)), or with the average of integrals of methyl group and methylene protons (for PSar) in the $400 \mathrm{MHz}{ }^{1} \mathrm{H}$ NMR spectra.

Infrared spectroscopy was performed on a Jasco FT/IR-4100 with an ATR sampling accessory (MIRacle, Pike Technologies) using 16 scans per measurement. IR spectra were analyzed using Spectra Manager 2.0 (Jasco). GPC (Gel permeation chromatography) in HFIP was performed with $3 \mathrm{~g} \mathrm{l}^{-1}$ potassium trifluoroacetate at $40{ }^{\circ} \mathrm{C}$. The columns were packed with modified silica (PFG columns, particle size: $7 \mu \mathrm{m}$, porosity: 100 and $1000 \AA$ ). A refractive index detector (G 1362A RID, Jasco) and a UV/vis detector (UV-2075 Plus, JASCO) was used to detect the polymer. Molecular weights were calculated using calibration performed with PMMA standards (Polymer Standards Services $\mathrm{GmbH}$ ). As the internal standard, toluene was used. Melting points were determined on Mettler Toledo FP62 melting point apparatus at a heating rate of $5{ }^{\circ} \mathrm{C} \mathrm{min}^{-1}$. For the MTT assay, a CellTiter 96 ${ }^{\circledR}$ Non-Radioactive Cell Proliferation Assay kit was purchased from Promega (Madison, USA). Adsorption was measured using a Dynex MRX TC Revelation microtiter plate reader (Dynex Technologies, Chantilly, VA).

A Complement Component 5a (C5a) ELISA kit was obtained from antibodies-online $\mathrm{GmbH}$ (Aachen, Germany).

\section{Synthetic procedures}

3-Azido-1-aminopropane. 3-Azido-1-aminopropane was synthesized according to the literature. ${ }^{44}$ 3-Chloropropylamine hydrochloride $(5.04 \mathrm{~g}, 0.039 \mathrm{mmol}, 1 \mathrm{eq}$.) and sodium azide ( $7.57 \mathrm{~g}, 0.116 \mathrm{mmol}, 3$ eq.) were dissolved in $40 \mathrm{ml} \mathrm{H}_{2} \mathrm{O}$ and heated to $80{ }^{\circ} \mathrm{C}$ for $21 \mathrm{~h}$. The reaction mixture was concentrated in vacuo. $50 \mathrm{ml}$ of diethyl ether were added, followed by the addition of $3.5 \mathrm{~g} \mathrm{KOH}$ in small portions with continuous stirring and cooling in an ice bath to keep the temperature below $10^{\circ} \mathrm{C}$. The aqueous layer was extracted five times with
$20 \mathrm{~mL}$ diethyl ether. The organic phases were combined and dried over sodium sulphate. The ether was evaporated in vacuo and the crude product (yellow oil) was purified by fractionated distillation and stored at $-20{ }^{\circ} \mathrm{C}(1.60 \mathrm{~g}, 0.016 \mathrm{mmol}, 41 \%)$. ${ }^{1} \mathrm{H}$ NMR $\left(400 \mathrm{MHz}, \mathrm{CDCl}_{3}\right) \delta[\mathrm{ppm}]=3.36\left(\mathrm{t},{ }^{3} \mathrm{~J}_{\mathrm{H}, \mathrm{H}}=6.70 \mathrm{~Hz}\right.$, $\left.2 \mathrm{H}, \mathrm{CH}_{2}-\mathrm{N}_{3}\right), 2.79\left(\mathrm{t},{ }^{3} J_{\mathrm{H}, \mathrm{H}}=6.80 \mathrm{~Hz}, 2 \mathrm{H}, \mathrm{CH}_{2}-\mathrm{NH}_{2}\right), 1.71$ (quint, $\left.{ }^{3} \mathrm{~J}_{\mathrm{H}, \mathrm{H}}=6.76 \mathrm{~Hz}, 2 \mathrm{H}, \mathrm{CH}_{2}-\mathrm{CH}_{2}-\mathrm{CH}_{2}\right), 1.21\left(\mathrm{~s}, 2 \mathrm{H}, \mathrm{CH}_{2}-\mathrm{NH}_{2}\right)$.

${ }^{13} \mathrm{C}$ NMR $\left(400 \mathrm{MHz}, \mathrm{CDCl}_{3}\right) \delta[\mathrm{ppm}]=49.13\left(\mathrm{CH}_{2}-\mathrm{N}_{3}\right), 39.31$ $\left(\mathrm{CH}_{2}-\mathrm{NH}_{2}\right), 32.43\left(\mathrm{CH}_{2}-\mathrm{CH}_{2}-\mathrm{CH}_{2}\right)$.

IR azide $\nu\left[\mathrm{cm}^{-1}\right]=2088.5$.

Sarcosine- $N$-carboxyanhydride. The synthesis of sarcosine NCA was adapted from the literature and modified. ${ }^{45}$

Sarcosine ( $15.16 \mathrm{~g}, 170.2 \mathrm{mmol}, 1$ eq.) was weighed into a pre-dried three-necked flask and dried under vacuum for 1 hour. $300 \mathrm{~mL}$ absolute (abs.) THF was added under a steady flow of nitrogen. The apparatus was connected to two gas washing bottles filled with an aqueous sodium hydroxide solution. Diphosgene (16.26 ml, $134 \mathrm{mmol}, 0.8$ eq.) was added slowly via a syringe. The colorless suspension was heated to $70{ }^{\circ} \mathrm{C}$, yielding a clear solution after 3 hours of stirring. The solvent was evaporated under reduced pressure, yielding a brown oil as the crude reaction product. The oil was heated to $50{ }^{\circ} \mathrm{C}$ and dried under reduced pressure to obtain an amorphous solid. The crude reaction product was redissolved in $60 \mathrm{~mL}$ THF and precipitated with $300 \mathrm{~mL}$ abs. $n$-hexane. The precipitate was filtered off under a $\mathrm{N}_{2}$ atmosphere and dried with a stream of dry nitrogen for $60-90$ minutes to remove the residual traces of solvents. The next day, the product was dried under high vacuum for 2 hours in the sublimation apparatus and subsequently sublimated at $80-85^{\circ} \mathrm{C}$ and $<1 \times 10^{-2}$ mbar. The product was collected from the sublimation apparatus in a glove box on the same day. Colorless crystals were obtained $(50-67 \%) . \mathrm{mp}=104.3{ }^{\circ} \mathrm{C} ;{ }^{1} \mathrm{H}$ NMR $\left(300 \mathrm{MHz}, \mathrm{CDCl}_{3}\right) \delta[\mathrm{ppm}]=$ $2.86\left(\mathrm{~s}, 3 \mathrm{H}, \mathrm{NH}-\mathrm{CH}_{3}\right), 4.22$ (s, $\left.2 \mathrm{H}, \mathrm{NH}-\mathrm{CH}_{2}-\mathrm{CO}\right)$.

$\mathrm{N}$-e-Trifluoroacetyl-t-lysine $\mathrm{N}$-carboxyanhydride. $12.5 \mathrm{~g}$ (51.6 mmol) of $N$ - $\varepsilon$-trifluoroacetyl-protected lysine were weighed into a pre-dried three-necked flask and dried under vacuum for 1 hour. The solid was suspended in $300 \mathrm{~mL}$ of absolute THF under a steady flow of dry nitrogen. The apparatus was connected to two gas washing bottles filled with an aqueous sodium hydroxide solution. Diphosgene $(5.50 \mathrm{~mL}, 45.6 \mathrm{mmol})$ was added slowly via a syringe and the nitrogen stream was reduced. The colorless suspension was mildly refluxed for 2 hours, yielding a cloudy solution. Overnight, a steady flow of dry nitrogen was passed through the solution, removing excess phosgene and $\mathrm{HCl}$. The solvent was evaporated under reduced pressure. The crude reaction product was redissolved in absolute THF and precipitated with an excess of dry $n$-hexane. The solid was collected by filtration under a dry nitrogen atmosphere and washed with $n$-hexane. The crude product was recrystallized twice with absolute THF/n-hexane. $10.43 \mathrm{~g}$ of the purified product ( $39.0 \mathrm{mmol}$; $75 \%$ yield; colorless needle) were obtained and stored in a Schlenk tube at $-80^{\circ} \mathrm{C} . \mathrm{mp}=101^{\circ} \mathrm{C}$; ${ }^{1} \mathrm{H}$ NMR $\left(300 \mathrm{MHz}\right.$, DMSO- $\left.\mathrm{d}_{6}\right): \delta[\mathrm{ppm}]=1.42-1.24(2 \mathrm{H}, \mathrm{m}$, $\left.-\mathrm{CH}-\mathrm{CH}_{2}-\mathrm{CH}_{2}-\mathrm{CH}_{2}-\mathrm{CH}_{2}-\mathrm{NH}-\right)$, 1.53-1.46 $\left(2 \mathrm{H}\right.$, quint, ${ }^{3} \mathrm{~J}_{\mathrm{H}, \mathrm{H}}=$ $\left.7.13 \mathrm{~Hz},-\mathrm{CH}-\mathrm{CH}_{2}-\mathrm{CH}_{2}-\mathrm{CH}_{2}-\mathrm{CH}_{2}-\mathrm{NH}-\right), 1.79-1.61(2 \mathrm{H}, \mathrm{m}$, 
$\left.-\mathrm{CH}-\mathrm{CH}_{2}-\mathrm{CH}_{2}-\mathrm{CH}_{2}-\mathrm{CH}_{2}-\mathrm{NH}-\right), 3.17\left(2 \mathrm{H}, \mathrm{q},{ }^{3} \mathrm{~J}_{\mathrm{H}, \mathrm{H}}=6.3 \mathrm{~Hz},-\right.$ $\left.\mathrm{CH}_{2}-\mathrm{NH}-\right), 4.43\left(1 \mathrm{H}, \mathrm{t},{ }^{3} J_{\mathrm{H}, \mathrm{H}}=6.3 \mathrm{~Hz},-\mathrm{CO}-\mathrm{CH}-\mathrm{CH}_{2}-\right), 9.09(1 \mathrm{H}$, $\mathrm{s},-\mathrm{NH}-\mathrm{CO}-\mathrm{O}-\mathrm{CO}-), 9.40\left(1 \mathrm{H}, \mathrm{s},-\mathrm{NH}-\mathrm{CO}-\mathrm{CF}_{3}\right)$.

$\boldsymbol{\gamma}$-Benzyl-L-glutamate- $\boldsymbol{N}$-carboxyanhydride. The synthesis of $\gamma$-benzyl-L-glutamate NCA was adapted from the literature and modified. ${ }^{46}$

$9.75 \mathrm{~g}$ (41.1 mmol, 1 eq.) of $\mathrm{H}-\mathrm{Glu}(\mathrm{OBzl})-\mathrm{OH}$ were weighed into a three-necked round-bottomed flask equipped with a magnetic stir bar, a condenser, a rubber septum and a glass stopper and dried under vacuum. After 30 minutes, $100 \mathrm{~mL}$ abs. tetrahydrofuran (THF) was added to the solid, resulting in a colorless suspension. The suspension was heated to $70{ }^{\circ} \mathrm{C}$, and diphosgene ( $4 \mathrm{~mL}, 32.9 \mathrm{mmol}, 0.8 \mathrm{eq}$.) was added to the mixture and stirred for $1.5 \mathrm{~h}$. The suspension turned into a clear, yellow solution. After the reaction mixture had cooled down, a stream of dried $\mathrm{N}_{2}$ was passed through the mixture overnight to remove the excess of $\mathrm{HCl}$ and diphosgene. The next day, the resulting orange oil was evacuated to dryness. The product was purified by recrystallization from THF and $n$-hexane twice. The colorless precipitate was isolated by filtration under $\mathrm{N}_{2} .7 .93 \mathrm{~g}(0.03 \mathrm{mmol}, 73 \%)$ of colorless crystals were obtained. $\mathrm{mp}=93.7{ }^{\circ} \mathrm{C} ;{ }^{1} \mathrm{H} \mathrm{NMR}\left(400 \mathrm{MHz}, \mathrm{CDCl}_{3}\right)$ $\delta[\mathrm{ppm}]=2.23-2.00\left(\mathrm{~m}, 1 \mathrm{H}, \beta-\mathrm{CH}_{2}\right), 2.35-2.22\left(\mathrm{~m}, 1 \mathrm{H}, \beta-\mathrm{CH}_{2}\right)$, $2.60\left(\mathrm{t}, 2 \mathrm{H},{ }^{3} \mathrm{~J}_{\mathrm{H}, \mathrm{H}}=6.7 \mathrm{~Hz}, \gamma-\mathrm{CH}_{2}\right), 4.45-4.30(\mathrm{~m}, 1 \mathrm{H}, \alpha-\mathrm{CH})$, $5.14\left(\mathrm{~s}, 2 \mathrm{H},-\mathrm{OCH}_{2}\right), 6.3(\mathrm{~s}, 1 \mathrm{H}, \mathrm{CH}-\mathrm{NH}-\mathrm{CO}), 7.42-7.32(\mathrm{~m}, 5 \mathrm{H}$, -benzyl).

Polysarcosine. In a typical experiment, $461.8 \mathrm{mg}$ of SarNCA (4.012 $\mathrm{mmol}$ ) were transferred under nitrogen counter flow into a pre-dried Schlenk tube equipped with a stir bar and again dried in a vacuum for 30 minutes. The NCA was then dissolved in $3.5 \mathrm{ml}$ of dry DMF. A stock solution of $9.38 \mu \mathrm{l}$ (7.00 mg, $0.080 \mathrm{mmol}, 1 / 100$ eq., $M / I=100$ ) of neopentylamine in $2 \mathrm{~mL}$ DMF was prepared and $1 \mathrm{~mL}$ of this stock solution was added to the monomer solution via a syringe. The solution was stirred at $40{ }^{\circ} \mathrm{C}$ and kept at a constant pressure of $1.25 \mathrm{bar}$ of dry nitrogen via the Schlenk line to prevent impurities from entering the reaction vessel while allowing $\mathrm{CO}_{2}$ to escape. Completion of the reaction was confirmed by IR spectroscopy (disappearance of the NCA peaks (1853 and $1786 \mathrm{~cm}^{-1}$ )). Directly after completion of the reaction, the polymer was precipitated in cold diethyl ether and centrifuged (4500 rpm at $4{ }^{\circ} \mathrm{C}$ for $\left.15 \mathrm{~min}\right)$. After discarding the liquid fraction, new ether was added and the polymer was resuspended using sonication. The suspension was centrifuged again and the procedure was repeated. The polymer was then dissolved in $\mathrm{H}_{2} \mathrm{O}$ and lyophilized to obtain a fluffy powder $(277.7 \mathrm{mg}$, 96\%). For different chain lengths, yields ranged from $87 \%$ to $96 \%$. ${ }^{1} \mathrm{H}$ NMR: (400 MHz, DMSO-d $\left.{ }_{6}\right): \delta[\mathrm{ppm}]=0.88-0.79(\mathrm{~m}$, ini, 9H, $\left.-\mathrm{C}\left(\mathrm{CH}_{3}\right)_{3}\right), 2.58-3.11$ (br, 3nH, N-CH 3$), 3.73-4.57$ (br, 2nH, $\left.-\mathrm{CO}-\mathrm{CH}_{2}-\mathrm{N}\right)$.

Polymerization using 3-azido-1-aminopropane, propargylamine and DBCO-amine was carried out in the same way. Yields were 91 and 96\% (3-azido-1-aminopropane), 88 and 91\% (propargylamine) and 99 and 100\% (DBCO-amine). Initiator signals used for integration: 3-azido-1-aminopropane ${ }^{1} \mathrm{H}$ NMR (400 MHz, DMSO-d $\left.{ }_{6}\right) \delta[\mathrm{ppm}]=1.71-1.61(\mathrm{~m}, 2 \mathrm{H}$,
$-\mathrm{CH}_{2}-\mathrm{CH}_{2}-\mathrm{N}_{3}$ ). DBCO-amine ${ }^{1} \mathrm{H}$ NMR (400 MHz, DMSO-d 6 ) $\delta[\mathrm{ppm}]=7.86-7.10$ (m, 8H, benzylic protons); initiator signals from propargylamine were not visible due to overlap with polymer backbone signals.

Poly $(\boldsymbol{\gamma}$-benzyl-t-glutamate). Polymerizations and work-up were carried out as described above. For different chain lengths, yields ranged from $77 \%$ to $89 \%$. ${ }^{1} \mathrm{H}$ NMR $(400 \mathrm{MHz}$, DMSO-d $\left._{6}\right) \delta[\mathrm{ppm}]=0.82\left(\mathrm{br}, 9 \mathrm{H}\left(\mathrm{CH}_{3}\right)_{3}\right), 1.56-2.44(\mathrm{br}, 4 \mathrm{nH}$, $\beta, \gamma-\mathrm{CH}_{2}$ ), 3.71-4.44 (br, $\left.1 \mathrm{nH}, \alpha-\mathrm{CH}\right), 4.73-5.25$ (br, $2 \mathrm{nH}$, $-\mathrm{OCH}_{2} \mathrm{Ph}$ ), 6.99-7.57 (br, 5nH, -Ph), 7.65-8.71 (br, 1nH, $-\mathrm{NHCO})$.

Polymerization using propargylamine, 3-azido-1-aminopropane and DBCO-amine as initiators was carried out in the same way. Yields were 88 and 77\% (3-azido-1-aminopropane), 83 and 95\% (DBCO-amine), 89 and 74\% (propargylamine) for different chain lengths. Initiator signals used for integration: 3-azido-1-aminopropane ${ }^{1} \mathrm{H} \quad \mathrm{NMR} \quad\left(\begin{array}{llll}400 & \left.\mathrm{MHz}, \quad \mathrm{DMSO}-\mathrm{d}_{6}\right)\end{array}\right.$ $\delta[\mathrm{ppm}]=1.73-1.65\left(\mathrm{~m}, 2 \mathrm{H}, \mathrm{CH}_{2}-\mathrm{CH}_{2}-\mathrm{CH}_{2}\right), 3.18-3.10(\mathrm{~m}, 2 \mathrm{H}$, $\mathrm{CH}_{2}-\mathrm{NH}_{2}$ ); propargylamine ${ }^{1} \mathrm{H} \mathrm{NMR}$ (400 MHz, DMSO-d ${ }_{6}$ ) $\delta[\mathrm{ppm}]=3.07(\mathrm{~m}, 1 \mathrm{H},-\mathrm{CCH})$, initiator signals from DBCOamine could not be detected due to overlap with polymer backbone signals.

$\operatorname{Poly}(\boldsymbol{N}-\boldsymbol{\varepsilon}$-trifluoroacetyl-L-lysine). Polymerizations were carried out as described above. After completion of the reaction had been confirmed by IR spectroscopy (disappearance of the NCA peaks (1853 and $\left.1786 \mathrm{~cm}^{-1}\right)$ ), the polymer was directly modified at the end group without further purification when using neopentylamine as the initiator. After precipitation in diethyl ether, the polymer was freeze-dried from $\mathrm{MeOH} / \mathrm{H}_{2} \mathrm{O}$. For different chain lengths, yields were 49 and $71 \%$. ${ }^{1} \mathrm{H}$ NMR $\left(400 \mathrm{MHz}, \mathrm{DMSO}_{\mathrm{d}}\right) \delta[\mathrm{ppm}]=0.82\left(\mathrm{~m},-\mathrm{C}\left(\mathrm{CH}_{3}\right)_{3}\right), 0.98-2.29$ (br, 6nH, $\beta, \gamma, \delta-\mathrm{CH}_{2}$ ), 2.86-3.24 (br, 2nH, $-\mathrm{CH}_{2}-\mathrm{CH}_{2}-\mathrm{NH}-\mathrm{CO}$ ), 3.53-4.51 (br, 1nH, $\alpha-\mathrm{CH} 2$ ), 7.21-8.89 (br, $1 \mathrm{nH},-\mathrm{NH}-\mathrm{CO}$ ), 9.10-9.55 (br, $1 \mathrm{nH},-\mathrm{CH}_{2}-\mathrm{CH}_{2}-\mathrm{NH}-\mathrm{CO}$ ).

Polymerization using 3-azido-1-aminopropane was carried out in the same way as described above. Yields were 73 and $77 \%$ for different chain lengths. Initiator signals from 3-azido1-aminopropane could not be detected due to overlap with polymer backbone signals.

$S$-Benzyl thiosuccinic acid. The synthesis was adapted from the literature. ${ }^{47}$ In a round bottomed flask equipped with a rubber septum and a magnetic stir bar, succinic anhydride (2.26 g, $22.6 \mathrm{mmol}, 1$ eq.) and 4-(dimethylamino)-pyridine (138 mg, $1.15 \mathrm{mmol}, 0.05$ eq.) were dissolved in $25 \mathrm{~mL}$ dry acetonitrile/pyridine 9:1 (v/v) and stirred at room temperature for $10 \mathrm{~min}$ under a nitrogen atmosphere. Benzyl mercaptan (2.95 $\mathrm{mL}, 3.11 \mathrm{~g}, 25.1 \mathrm{mmol}$ ) was added and the reaction mixture was stirred for 4 days at room temperature. For purification, the solvent was evaporated in vacuo and the residue was dissolved in $30 \mathrm{~mL}$ of aqueous sodium hydrogen carbonate solution ( $\mathrm{pH}$ 8.2). The aqueous phase was extracted three times with $20 \mathrm{~mL}$ of diethyl ether. The aqueous phase was then acidified with $5 \mathrm{M} \mathrm{HCl}$ and colorless crystals precipitated from the solution, which were filtered off and subsequently washed with cold $0.1 \mathrm{M} \mathrm{HCl}$ and with ice-cold water. The product was dried in a vacuum desiccator. The reaction flask 
was rinsed with an aqueous $\mathrm{NaHCO}_{3}$ solution and the above steps were repeated. Overall yield of colorless crystals: $2.63 \mathrm{~g}$ (11.7 mmol, 52\%). FD-MS = $224.2 \mathrm{~g} \mathrm{~mol}^{-1} .{ }^{1} \mathrm{H}$ NMR $(400 \mathrm{MHz}$, $\left.\mathrm{CDCl}_{3}\right): \delta[\mathrm{ppm}]=2.74\left(\mathrm{t},{ }^{3} J_{\mathrm{H}, \mathrm{H}}=7.0 \mathrm{~Hz}, 2 \mathrm{H},-\mathrm{CH}_{2} \mathrm{COS}\right), 2.91(\mathrm{t}$, $\left.{ }^{3} J_{\mathrm{H}, \mathrm{H}}=6.8 \mathrm{~Hz}, 2 \mathrm{H},-\mathrm{SCH}_{2}\right), 4.15\left(\mathrm{~s}, 2 \mathrm{H},-\mathrm{CH}_{2} \mathrm{CH}_{2} \mathrm{COS}\right)$, 7.57-6.95 (m, 5H, -benzyl), 11.1 (s, 1H, - $\mathrm{COOH}) .{ }^{13} \mathrm{C}$ NMR $\left(100 \mathrm{MHz}, \mathrm{CDCl}_{3}\right): \delta[\mathrm{ppm}]=29.1\left(-\mathrm{CH}_{2} \mathrm{COS}\right), 33.4\left(-\mathrm{SCH}_{2}\right)$, 37.9 ( $-\mathrm{CH}_{2} \mathrm{CH}_{2} \mathrm{COS}$ ), 127.5 (para-C), 128.8 (ortho-C), 128.9 (meta-C), 137.4 (- $\left.\mathrm{CH}_{2} \mathrm{COS}\right), 178.32$ (ipso-C), 197.1 (-COOH).

End group functionalization. All end group modifications with $S$-benzyl thiosuccinic acid and Boc-L-Cys(Trt) were carried out in the same way. End group modification of PLys(TFA) was conducted in situ without prior isolation of the homopolymer. For lyophilization, it was preceded as for homopolymer synthesis.

$183.0 \mathrm{mg}$ ( $0.073 \mathrm{mmol}, 1 \mathrm{eq}$.) of PSar were weighed into a flame-dried Schlenk flask and dried under vacuum for 30 minutes. The polymer was then dissolved in $2 \mathrm{~mL}$ of dry DMF. In another Schlenk flask, $163.9 \mathrm{mg}$ (0.731 mmol, 10 eq.) $S$-benzyl-thiosuccinic acid, together with $305.4 \mathrm{mg}$ (0.805 mmol, 11 eq.) $N, N, N^{\prime}, N^{\prime}$-tetramethyl-O-( $1 H$-benzotriazol1-yl)uronium hexafluorophosphate (HBTU) and $108.4 \mathrm{mg}$ (0.802 mmol, 11 eq.) hydroxybenzotriazole (HOBt) were dissolved in $2 \mathrm{~mL}$ of dry DMF while cooling the flask in an ice bath. $273.1 \mu \mathrm{l}$ (207.6 mg, $1.606 \mathrm{mmol}, 22 \mathrm{eq}$.) of DIPEA were directly added and the mixture was stirred for 30 minutes with cooling. The resulting activated ester was subsequently added to the polymer solution and stirred at room temperature for $65 \mathrm{~h}$.

For purification, the reaction mixture was precipitated in diethyl ether and centrifuged (4500 rpm at $4{ }^{\circ} \mathrm{C}$ for $15 \mathrm{~min}$ ). After discarding the liquid fraction, new $\mathrm{Et}_{2} \mathrm{O}$ was added and the polymer was resuspended using sonication. The suspension was centrifuged again and the procedure was repeated. The polymer was then dissolved in $\mathrm{H}_{2} \mathrm{O}$ and dialyzed for 4 days against MilliQ-water (MWCO $=1000 \mathrm{~g} \mathrm{~mol}^{-1}$ or $3500 \mathrm{~g} \mathrm{~mol}^{-1}$, depending on the molecular weight) and lyophilized. For different chain lengths, yields ranged from 67 to $90 \%$. Degrees of end group modification were quantitative according to ${ }^{1} \mathrm{H}$ NMR (additional signal in ${ }^{1} \mathrm{H}$ NMR (400 MHz, DMSO- $\mathrm{d}_{6}$ ) $\delta[\mathrm{ppm}]=7.19-7.34(\mathrm{~m}, 5 \mathrm{nH},-$ benzyl $))$. End group modification with Boc-L-Cys(Trt) was carried out in the same way. Additional signals in ${ }^{1} \mathrm{H}$ NMR $\left(400 \mathrm{MHz}, \mathrm{DMSO}-\mathrm{d}_{6}\right) \delta[\mathrm{ppm}]=$ 7.24-7.34 (m, 15nH, -trityl), 1.36 (s, 9nH, -C( $\left.\left.\mathrm{CH}_{3}\right)_{3}\right)$.

PLys(TFA) polymers were precipitated in diethyl ether and extensively dialyzed against $\mathrm{H}_{2} \mathrm{O} / \mathrm{MeOH}$ 1:9. Polymers were freeze-dried from $\mathrm{H}_{2} \mathrm{O} / \mathrm{MeOH}$. For different chain lengths, yields ranged from 49 to $71 \%$. Degrees of end group modification ranged from $94 \%$ to quantitative according to ${ }^{1} \mathrm{H}$ NMR (additional signals from Boc-L-Cys(Trt) modification in ${ }^{1} \mathrm{H}$ NMR $\left(400 \mathrm{MHz}, \mathrm{DMSO}_{6}\right) \delta[\mathrm{ppm}]=7.17-7.39$ (m, 15nH, -trityl)).

Deprotection of Boc-L-Cys(Trt)-modified polypeptides and polypeptoids. In a typical experiment, $79.4 \mathrm{mg}$ of polypeptide (9.86 $\mu \mathrm{mol}, 1$ eq., PSar) were dissolved with a minimal amount of trifluoroacetic acid (TFA) and immediately, 4 equivalents of triisopropyl silane (TIPS) were added. The mixture was stirred for 30 minutes at room temperature and was then precipitated into cold diethyl ether and centrifuged $\left(4500 \mathrm{rpm}\right.$ at $4{ }^{\circ} \mathrm{C}$ for $15 \mathrm{~min}$ ). After discarding the liquid fraction, new diethyl ether was added and the polymer was resuspended using sonication. The suspension was centrifuged again and the procedure was repeated. Products were freeze-dried according to homopolymer synthesis. Deprotection of trityl and boc protecting groups was judged to be complete when the corresponding chemical shifts had disappeared in ${ }^{1} \mathrm{H}$ NMR spectra.

CuAAC, hydrophilic conditions. Polymers were weighed into a Schlenk tube (1 eq. of each) equipped with a magnetic stir bar and dissolved in $2 \mathrm{~mL} \mathrm{H}_{2} \mathrm{O}$. A stock solution of ascorbic acid in water was prepared and $50 \mathrm{~mol} \%$ were added to the mixture $(0.5 \mathrm{~mL})$. The solvent was degassed by freeze-pumpthaw cycles. $15 \mu \mathrm{L}$ of a $\mathrm{CuSO}_{4}$ stock solution was added $(5 \mathrm{~mol}$ $\%)$. After the third freeze-pump-thaw cycle, the reaction mixture was heated to $40{ }^{\circ} \mathrm{C}$ for $3 \mathrm{~d}$, followed by dialysis against $\mathrm{H}_{2} \mathrm{O}$ to remove the residual copper and lyophilized, yielding a fluffy colourless solid.

CuAAC, hydrophobic and amphiphilic conditions. Polymers were dissolved in $2 \mathrm{~mL}$ of dry DMF in a Schlenk tube (1 eq. of each) equipped with a magnetic stir bar. PMDETA was added via a pipette with $\mathrm{N}_{2}$ counter flow. The mixture was degassed by three freeze-pump-thaw cycles and transferred to a second Schlenk tube containing $\mathrm{Cu}(\mathrm{I}) \mathrm{Br}$ (2 eq.) with a syringe that had been previously purged with nitrogen. The reaction mixture was heated to $40{ }^{\circ} \mathrm{C}$ for $70 \mathrm{~h}$, precipitated in $\mathrm{H}_{2} \mathrm{O} /$ methanol $1: 9$ to remove the residual copper to allow NMR analysis and freeze-dried from dioxane. Samples were analyzed by HFIP GPC.

SPAAC. Ligations between hydrophilic polypeptides were conducted in $\mathrm{H}_{2} \mathrm{O}$. Ligations between hydrophobic and hydrophilic/amphiphilic polypeptides were conducted in DMF. In a typical experiment, 1 eq. of each polymer was weighed into a round-bottomed flask and dissolved in the appropriate solvent $\left(c=100 \mathrm{mg} \mathrm{mL}^{-1}\right)$. The reaction mixture was stirred for $70 \mathrm{~h}$ at $40{ }^{\circ} \mathrm{C}$. Aqueous samples were dialyzed against water $(\mathrm{MWCO}=$ 1000 and $3500 \mathrm{~g} \mathrm{~mol}^{-1}$ respectively) and lyophilized. Samples in DMF were precipitated in diethyl ether, washed twice and freeze-dried from dioxane. Samples were analyzed by HFIP-GPC.

NCL, hydrophilic conditions. $2 \mathrm{~mL}$ of $10 \mathrm{mM}$ PBS buffer $(\mathrm{pH}=7.4)$ were degassed for 45 minutes and MPAA and TCEP. $\mathrm{HCl}$ were added to yield final concentrations of $50 \mathrm{mM}$ and $30 \mathrm{mM}$ respectively. Polymers were transferred into a Schlenk tube (1 eq. each, $c=1 \mathrm{mM}$ ) equipped with a stir bar, the degassed buffer was added, the $\mathrm{pH}$ was adjusted if necessary and the reaction mixture was heated to $40{ }^{\circ} \mathrm{C}$ for 3 days. The reaction was quenched by the addition of $1 \mathrm{M} \mathrm{HCl}$ until the reaction mixture turned slightly acidic. The precipitated solid was separated from the reaction mixture by centrifugation (13 $300 \mathrm{rpm}, 15$ minutes) and the liquid fraction was freeze-dried and analyzed by HFIP GPC. For cell experiments, samples were dialyzed against phosphate buffer $(\mathrm{pH}=7.0)$ to remove the residual MPAA.

NCL, amphiphilic conditions. $1.4 \mathrm{mM}$ of polypeptide and $50 \mathrm{mM}$ of MPAA were weighed into a Schlenk tube and dried 
under vacuum for 30 minutes. DMF was degassed by three freeze-pump-thaw cycles and $0.5 \mathrm{~mL}$ were added to the solids using an $\mathrm{N}_{2}$-purged syringe. $40 \mathrm{mM}$ of TEA were added also via a purged syringe and the reaction mixture was heated to $40{ }^{\circ} \mathrm{C}$ for $70 \mathrm{~h}$ under an argon atmosphere. The reaction mixture was precipitated in diethyl ether and freeze-dried from $\mathrm{H}_{2} \mathrm{O}$. Samples were analyzed by HFIP GPC after treatment with TCEP. $\mathrm{HCl}$ overnight in $\mathrm{MeOH}$ and subsequent freeze-drying by the addition of an excess of water.

NCL with TCR CP (CGLRILLLKV). $1 \mathrm{~mL}$ of $4 \mathrm{M}$ urea buffer ( $\mathrm{pH}=7.09$ ) was degassed by passing $\mathrm{N}_{2}$ through the solution for 30 minutes. $50 \mathrm{mM}$ of MPAA and $20 \mathrm{mM}$ TCEP. $\mathrm{HCl}$ were added to the buffered solution, the $\mathrm{pH}$ was readjusted to 7.0 with $1 \mathrm{~N} \mathrm{NaOH}$ and degassed again. $9.10 \mathrm{mg}\left(9.99 \times 10^{-4} \mathrm{mmol}\right.$, 1 eq.) polysarcosine- $S$-benzyl-thiosuccinate $\left(X_{\mathrm{n}}=124\right.$, determined by $\left.{ }^{1} \mathrm{H} \mathrm{NMR}\right)$ and $2.30 \mathrm{mg}\left(2.04 \times 10^{-3} \mathrm{mmol}, 2\right.$ eq. $)$ of TCR CP were weighed into a plastic vial. $1 \mathrm{~mL}$ of the previously distilled THF was added, resulting in a colorless suspension. $4 \mathrm{M}$ urea buffer, containing MPAA and TCEP.HCl, was added and the suspension cleared up immediately. The reaction mixture was stirred for 2 days at $40{ }^{\circ} \mathrm{C}$. The reaction was quenched by the addition of a few drops of diluted hydrochloric acid solution until the reaction mixture had reached an acidic $\mathrm{pH}(\mathrm{pH} \approx 4)$. The reaction product was purified by dialysis $\left(\mathrm{MWCO}=3500 \mathrm{~g} \mathrm{~mol}^{-1}\right)$, first against phosphate buffer ( $\mathrm{pH}$ 7.0) to remove the residual MPAA and then against $\mathrm{H}_{2} \mathrm{O}$ for desalting. The product was lyophilized and $11.0 \mathrm{mg}(1.09 \times$ $10^{-3} \mathrm{mmol}, 92 \%$ ) of a colorless solid were obtained. Ligation product formation was confirmed by the disappearance of proton signals of the $S$-benzyl group and additional protons originating from the peptide. ${ }^{1} \mathrm{H}$ NMR (400 MHz, DMSO- $\mathrm{d}_{6}$ ) $\delta[\mathrm{ppm}]=1.79-1.16(\mathrm{~m}), 2.12-1.93(\mathrm{~m}), 8.23-7.09(\mathrm{~m})$. A distinct signal at $2.33 \mathrm{ppm}\left(\mathrm{t}(\mathrm{br}), 2 \mathrm{H},-\mathrm{CH}_{2} \mathrm{NH}_{2}\right.$ ) was from the lysine residue (CGLRILLLKV).

Determination of cellular toxicity of polymers with the MTT assay. Cytotoxicity of polymers was investigated with the MTT assay using the "CellTiter 96® Non-Radioactive Cell Proliferation Assay kit" (Promega, Madison, USA) according to manufacturer's protocol. HEK 293T cells were seeded onto 96-well culture plates at a concentration of $1.5 \times 10^{4}$ cells per well. Cells were incubated for 24 hours with $100 \mu \mathrm{L}$ of medium containing $0.1 \mathrm{mg} \mathrm{mL} \mathrm{m}^{-1}, 0.5 \mathrm{mg} \mathrm{mL}^{-1}$ and $1.0 \mathrm{mg} \mathrm{mL}^{-1}$ of polymers, respectively (hexaplicates). The next day $30 \mu \mathrm{L}$ of MTT substrate solution were added to each well and cells were cultured for another 2 hours. Subsequently, $100 \mu \mathrm{L}$ of "Solubilization Solution/Stop Mix" were added to each well. After 1 hour, the absorbance at $570 \mathrm{~nm}$ was measured.

Determination of the human complement fragment 5A concentration in human serum. $200 \mu \mathrm{L}$ of freshly obtained human serum were mixed with $200 \mu \mathrm{L}$ of aqueous polymer solution to yield a final polymer concentration of $1 \mathrm{mg} \mathrm{mL} \mathrm{m}^{-1}$, respectively. Serum-polymer solutions were incubated for 1 hour at $37{ }^{\circ} \mathrm{C}$. Polymer-induced activation of the complement system was assessed by applying the "Complement Component 5a (C5a) ELISA kit" (Antibodies-online GmbH, Aachen, Germany) according to the manufacturer's protocol.
For this, samples were diluted to $1: 2$ and $1: 4$ using the "Reference Standard and Sample Diluent" provided by the kit and subjected to further analysis.

\section{Results and discussion}

\section{Polymer synthesis and functionalization}

The aim of this work is to investigate the performance and the feasibility of the three most prominent ligation techniques - CuAAC, SPAAC and NCL - in a head-to-head comparison for the synthesis of block copolypeptides, polypept(o)ides and block polypept(o)ides. Therefore, we have synthesized various polypeptides and polypept(o)ides bearing C- and N-terminal functionalities (see Scheme 1).

While C-terminal azide or alkyne functionalities were introduced via primary amine initiators in the ring opening polymerization of $\alpha$-amino acid $N$-carboxyanhydrides, $\mathrm{N}$-terminal functionalities, namely cysteine and a thioester moiety, have been introduced by postpolymerization modification using peptide-coupling chemistry.

The polymers have been synthesized from the corresponding NCAs as previously reported (see Scheme 2). ${ }^{12,48}$ The employed NCAs, namely SarNCA, Lys(TFA)NCA and Glu(OBzl) NCA, were synthesized according to the Fuchs-Farthing method. ${ }^{49,50}$ Melting points (Glu(OBzl)NCA: $\mathrm{mp}=93.7^{\circ} \mathrm{C}$, Lys (TFA): $\mathrm{mp}=101{ }^{\circ} \mathrm{C}$, SarNCA: $\mathrm{mp}=104 .{ }^{\circ} \mathrm{C}$ ) were in good agreement with the literature or even higher than those reported which accounts for high purity. ${ }^{51-53}$ All the synthesized NCAs were stored at $-80^{\circ} \mathrm{C}$ under a nitrogen atmosphere over several months without any detectable degradation or oligomerization.

While heterotelechelic homopolymers with alkyne or azide end groups have been synthesized directly using 3-azido-1aminopropane (APA), propargylamine (PA) and DBCO-amine as the initiators for the ROP, polypept(o)ides for NCL were further modified at the N-terminus to incorporate $S$-benzyl thiosuccinic acid and Boc-L-cysteine(Trt). Polymers were characterized by HFIP-GPC and ${ }^{1} \mathrm{H}$ NMR. Analytical data of homopolymers are summarized in Table 1.

The degree of polymerization was calculated by ${ }^{1} \mathrm{H}$ NMR by comparing the signal of the end group with those of the repeating units. Monomodal Poisson-like molecular weight distributions were ensured by HFIP GPC. Unfortunately, for some polymer-end group combinations, the degree of polymerization $\left(X_{n}\right)$ could not be obtained by ${ }^{1} \mathrm{H}$ NMR due to an overlap of end group proton signals with polymer backbone signals (see the Experimental section). A comparison of $M_{\mathrm{n}(\mathrm{GPC})}$ and $\bigoplus_{\mathrm{GPC}}$ values of these polymers with their homologues with different end groups ensured that even in the absence of NMR studies, these polymers are of comparable chain length.

In general, homopolymers possess low dispersities $(\theta \leq$ 1.1) and high end-group integrities (see Table 1). This is remarkable since especially in the case of PLys(TFA), the dispersities determined by GPC are even overestimated due to the 


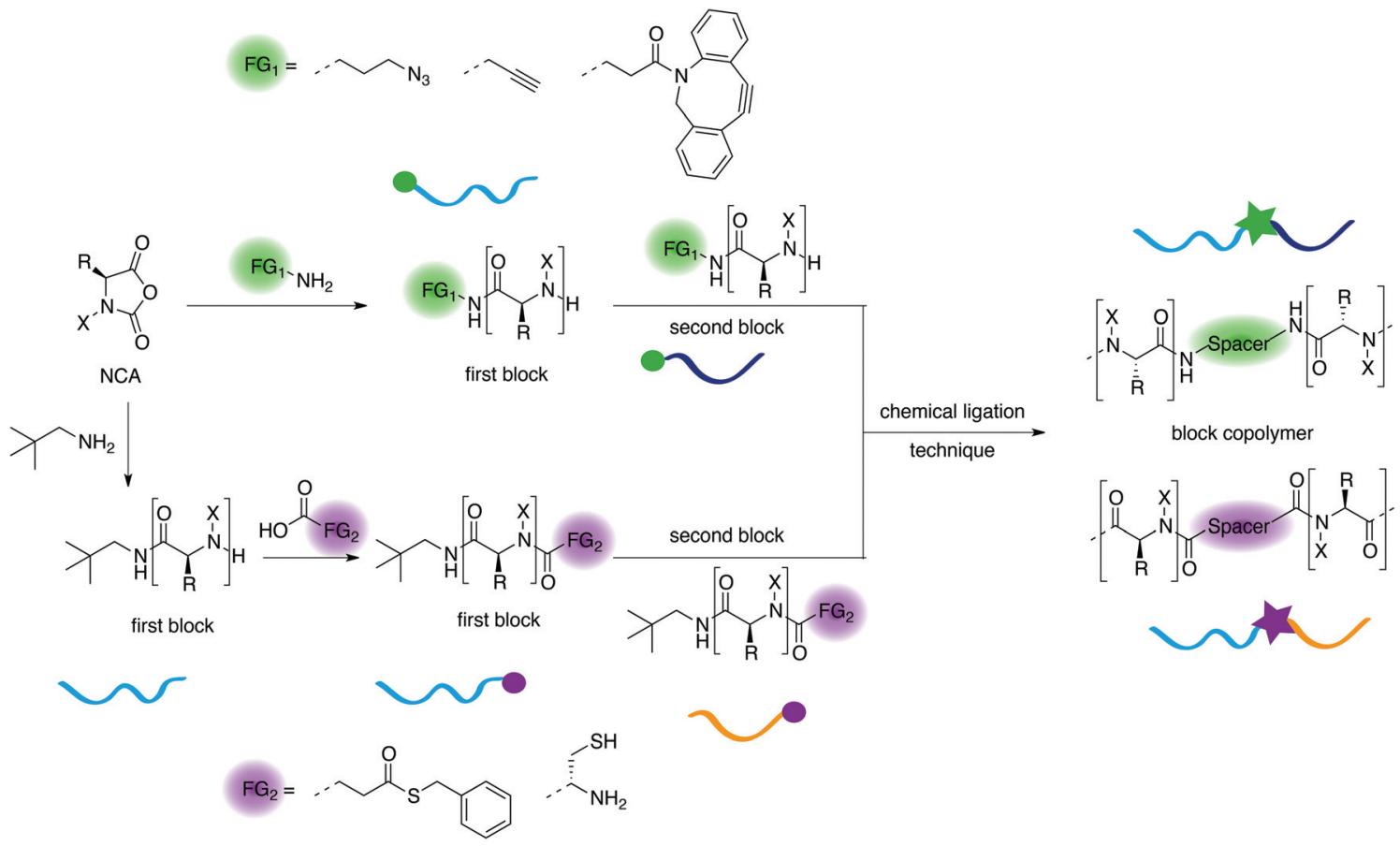

Scheme 1 General scheme of semitelechelic polymer synthesis and chemical ligation.

A)

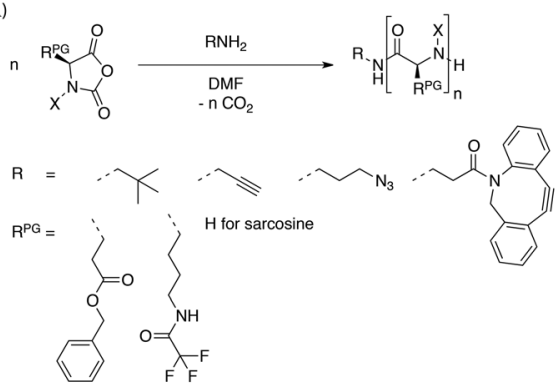

$\mathrm{X}=\mathrm{H}, \mathrm{Me}$ for sarcosine

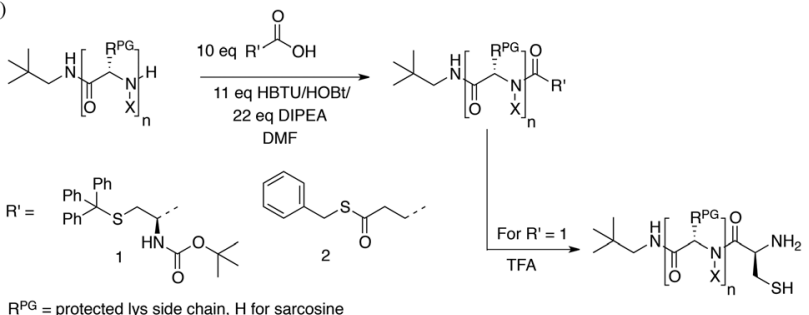

$\mathrm{R}^{\mathrm{PG}}=$ protected lys side chain, $\mathrm{H}$ for sarcosine

$\mathrm{X}=\mathrm{H}$, Me for sarcosine

Scheme 2 (A) Homopolymer synthesis by NCA polymerization; (B) end group functionalization of PSar (with 1 and 2) and of PLys(TFA) (only with 1).

coexistence of secondary structures differing in hydrodynamic volume as previously reported by Huesmann and coworkers. ${ }^{48}$ For PSar and PGlu polymers, dispersities are below 1.1 and for PLys(TFA), below 1.2 (see Table 1) and GPC elugrams indicate Poisson-like molecular weight distributions (see the ESI $\dagger$ ).
Neopentyl-terminated polymers were further modified at the N-terminus by standard peptide coupling chemistry using HOBt/HBTU/DIPEA (see Fig. 1). PSar was functionalized with $S$-benzyl thiosuccinic acid (BTS) and Boc-L-Cys(Trt) (Cys) respectively, and PLys(TFA) was functionalized with Cys. Modification of polypeptides with BTS did not give reliable degrees of end group modification. Although it has been shown that $\mathrm{N}$-terminal thioester synthesis can be achieved for low molecular weight peptides, ${ }^{47}$ the required long reaction times (2 days) for quantitative N-terminal modification led probably to aminolysis of the thioester, resulting in an inactivation of the end group by succinimide formation. Cyclisation cannot occur for PSar because of its methyl-substituted N-terminus. The degree of end group modification was determined by comparing the integral of the neopentylamine initiator's $t$-butyl group at $0.83-0.85 \mathrm{ppm}$ with the integral of the benzylic protons' signal of $S$-benzyl thiosuccinic acid $(5 \mathrm{H}, 7.2-7.3 \mathrm{ppm})$ and of the trityl protons' signal of Boc-L-Cys(Trt), respectively (15nH, 7.2-7.3 ppm and 9nH, $1.35 \mathrm{ppm}$ ), in DMSO-d 6 . For modification of PLys(TFA), only the trityl protons' signals were clearly detectable and used for the determination of the degree of end group modification (see Fig. 1A). The determined degrees of modification and analytical data of end group modified polymers can be found in Table 2 . Within the limits of accuracy, NMR data suggest nearly quantitative modification for the synthesized polymers (see Table 2). In addition, MALDI-TOF MS analysis of PSar polymers $\left(X_{\mathrm{n}}=50\right)$ containing five different functionalities (PA, DBCO, APA, NPA + BTS, NPA + Boc-L-Cys(Trt)) needed for ligation reactions further confirms the NMR data (see the ESI $\dagger$ ). 
Table 1 Characteristics of the synthesized homopolymers applying neopentylamine (NPA), 3-azido-1-aminopropane (APA), DBCO-amine (DBCO) and propargylamine (PA) as initiators

\begin{tabular}{lllrcr}
\hline & Polymer & Initiator & $X_{\mathrm{n}(\mathrm{NMR})}{ }^{a}$ & $\left.M_{\mathrm{n}(\mathrm{GPC})}{ }^{b} \mathrm{~kg} \mathrm{~mol}^{-1}\right)$ & $D_{\mathrm{GPC}}$ \\
\hline P1 & PSar & NPA & 58 & 16.1 & 1.06 \\
P2 & PSar & NPA & 117 & 24.3 & 1.09 \\
P3 & PSar & NPA & 46 & 13.3 & 1.05 \\
P4 & PSar & APA & 44 & 11.8 & 1.05 \\
P5 & PSar & APA & 96 & 20.6 & 1.08 \\
P6 & PSar & PA & n.d. & 14.9 & 1.08 \\
P7 & PSar & PA & n.d. & 25.0 & 1.10 \\
P8 & PSar & DBCO & 50 & 14.7 & 1.06 \\
P9 & PSar & DBCO & 119 & 24.6 & 1.06 \\
P10 & PGlu(OBzl) & APA & 64 & 14.8 & 1.05 \\
P11 & PGlu(OBzl) & APA & 108 & 21.7 & 1.07 \\
P12 & PGlu(OBzl) & PA & 72 & 14.7 & 1.05 \\
P13 & PGlu(OBzl) & PA & 117 & 19.9 & 1.06 \\
P14 & PGlu(OBzl) & DBCO & n.d. & 14.6 & 1.07 \\
P15 & PGlu(OBzl) & DBCO & n.d. & 24.9 & 1.14 \\
P16 & PLys(TFA) & NPA & 49 & 9.0 & 1.08 \\
P17 & PLys(TFA) & NPA & 111 & 18.5 & 1.11 \\
P18 & PLys(TFA) & APA & n.d. & 8.8 & \\
P19 & PLys(TFA) & APA & n.d. & 17.5 &
\end{tabular}

${ }^{a} X_{\mathrm{n}}$ was determined by ${ }^{1} \mathrm{H}$ NMR in DMSO- $\mathrm{d}_{6}$ by relating end group signals to those of the repeating unit. ${ }^{b} M_{\mathrm{n}}$ was determined relative to PMMA standards.
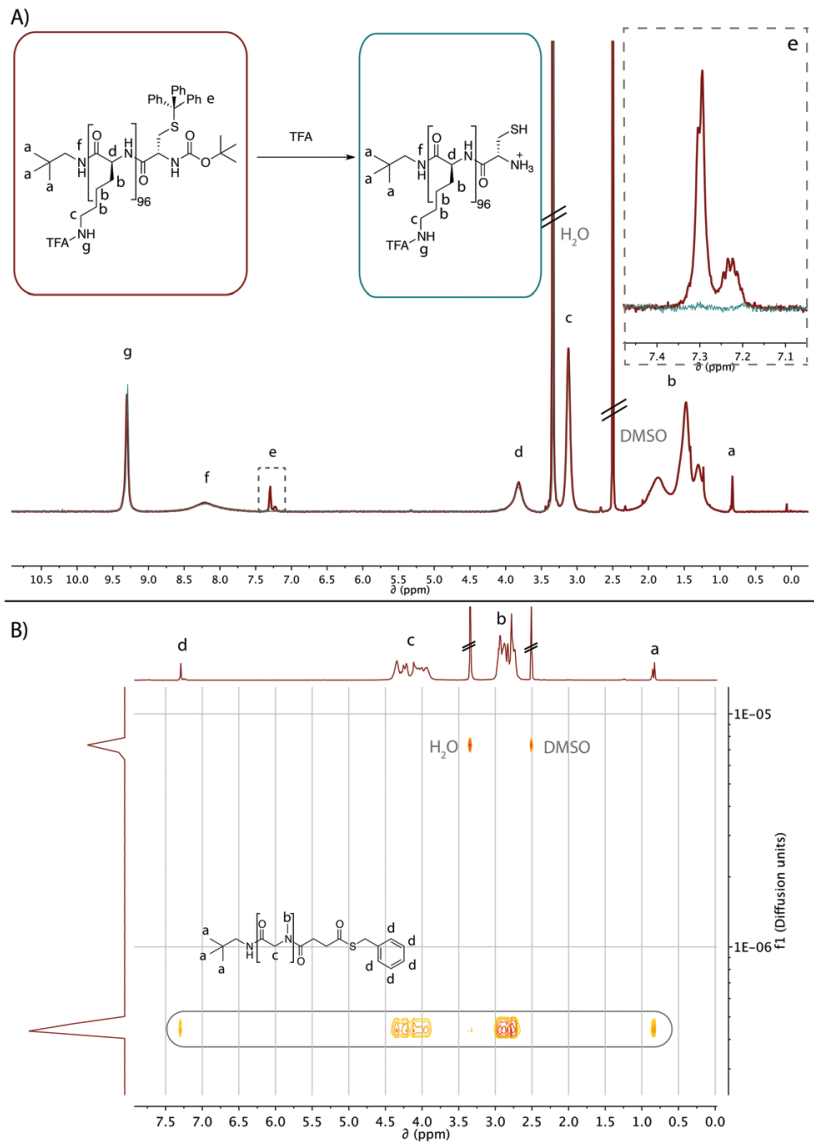

Fig. 1 (A) ${ }^{1} \mathrm{H}$ NMR spectrum of PLys(TFA) $100-$-Boc-L-Cys(Trt) before (red) and after (green) deprotection with TFA using TIPS as the scavenger for 30 minutes; (B) DOSY ${ }^{1} \mathrm{H}$ NMR spectrum of PSar ${ }_{50}-\mathrm{BTS}$.
The covalent attachment of the respective end groups to the polymer was verified by diffusion ordered spectroscopy (DOSY) (see Fig. 1B).

Finally, polymers modified with Boc-L-Cys(Trt) were subsequently deprotected in TFA for 30 minutes at room temperature using TIPS as a scavenger. The complete deprotection was monitored by ${ }^{1} \mathrm{H}$ NMR (see Fig. 1A).

Deprotection in TFA was chosen since PSar and PLys(TFA) are both soluble in TFA, and for purification the reaction mixture was precipitated in diethyl ether to easily remove the residual scavenger and the resulting hydrophobic products of the removed protecting groups (Trt).

\section{Ligation experiments}

Copper(I)-catalyzed alkyne-azide coupling (CuAAC), strainpromoted alkyne-azide 1,3-cycloaddition (SPAAC) and native chemical ligation (NCL) were performed as ligation techniques and reaction conditions (see Scheme 3 ) have been optimized.

Ligation experiments were performed for hydrophilic, hydrophilic/hydrophobic (amphiphilic) and hydrophobic conditions to provide coupling protocols for the synthesis of block copolymers consisting of blocks with different polarities. The employed polymer combinations are listed in Table 3. Two different degrees of polymerization $(M / I$ ratio $=50,100)$ were designed to study the influence of the chain length on the ligation efficacy. PSar was employed as a hydrophilic and nonionic block, while PLys(TFA) and PGlu(OBzl) served as hydrophobic blocks, with PLys(TFA) being slightly more polar than PGlu(OBzl) due to the amide bond in the side chain. Ligations were carried out between polypept(o)ides with similar chain lengths (50/50 and 100/100) to facilitate the analysis of coupling product formation by HFIP GPC.

NCL was only performed for hydrophilic and amphiphilic conditions for the reasons explained above and GPC samples were pretreated with TCEP.HCl to avoid misinterpretation by oxidation (dimer formation). All ligations were performed at 1 : 1 molar ratio of polymers and $40{ }^{\circ} \mathrm{C}$ for $70 \mathrm{~h}$ to ensure comparability between individual ligation reactions.

To quantify relative coupling efficiencies, GPC traces were fitted by Gaussian distributions (see Fig. 2), from which the peak areas were used to calculate the respective contents. This methodology is enabled since the GPC plots of homopolymers themselves can be fitted with negligible deviation by Gaussian distributions as expected for polymers having a Poisson-like molecular weight distribution. Ranges of the determined efficiencies are shown in Fig. 2 as well as elugrams of ligations between short polypept(o)ides (50/50) under hydrophilic conditions for CuAAC, SPAAC and NCL. The corresponding fit curves used for efficiency determination are also displayed.

The determined efficiencies for individual ligation experiments ranged from 53 to $88 \%$ (see the ESI $\dagger$ ). It has to be noted that the residual unreacted homopolymers can also be attributed to a non-equimolar ratio of the two employed homopolymers, since due to the intrinsic uncertainty of the determined chain lengths, an exact 1:1 ratio of functional end groups is hardly achievable. Coupling efficiencies are likely to be slightly 
Table 2 Characterization of end group modified PSar and PLys(TFA)

\begin{tabular}{|c|c|c|c|c|c|}
\hline Polymer & $\begin{array}{l}\text { End } \\
\text { group }\end{array}$ & $X_{\mathrm{n}(\mathrm{NMR})}{ }^{a}$ & $\bigoplus_{\mathrm{GPC}}$ & $M_{\mathrm{n}(\mathrm{GPC})}^{b}\left(\mathrm{~kg} \mathrm{~mol}^{-1}\right)$ & $\%$ Mod. $^{c}$ \\
\hline PSar (P1) & BTS & 60 & 1.06 & 14.9 & Quant. \\
\hline PSar (P3) & Cys & 44 & 1.12 & 11.9 & Quant. \\
\hline PSar (P2) & Cys & 117 & 1.25 & 18.8 & Quant. \\
\hline PLys(TFA) (P16) & Cys & 53 & 1.12 & 8.9 & 94 \\
\hline PLys(TFA) (P17) & Cys & 99 & 1.11 & 18.5 & Quant. \\
\hline
\end{tabular}

${ }^{a} X_{\mathrm{n}}$ was determined by ${ }^{1} \mathrm{H}$ NMR in DMSO- $\mathrm{d}_{6}$ by relating end group signals to those of the repeating unit. ${ }^{b} M_{\mathrm{n}}$ was determined relative to PMMA standards. ${ }^{c} \%$ Mod. was determined by ${ }^{1} \mathrm{H}$ NMR in DMSO- $\mathrm{d}_{6}$.

A)

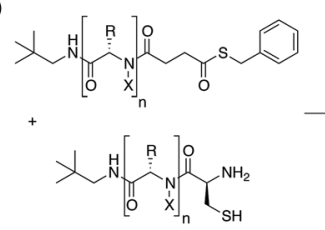

B)<smiles>C=CNC(=O)C(C)NC(=O)NC(C)NC(=O)NCCCN</smiles>

c)

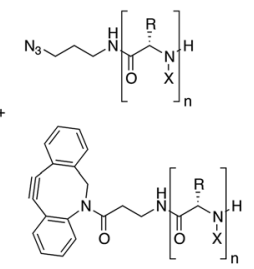

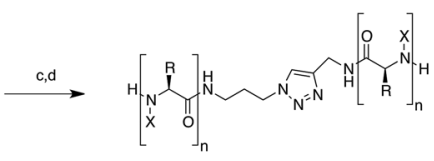

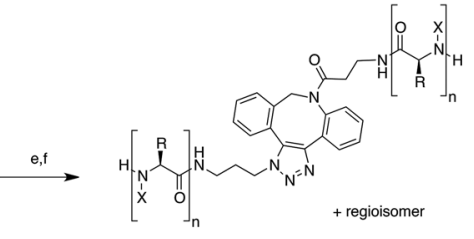

Scheme 3 Chemical ligation techniques used for block copolymer synthesis; (a) PBS (pH 7.4), 50 mM MPAA/20 mM TCEP. HCl; (b) DMF (abs.)/ $50 \mathrm{mM}$ MPAA/40 mM TEA; (c) $\mathrm{H}_{2} \mathrm{O} / 50 \mathrm{~mol} \%$ sodium ascorbate/5 mol\% $\mathrm{CuSO}_{4}$; (d) DMF (abs.)/2 eq. CuBr/4 eq. PMDETA; (e) $\mathrm{H}_{2} \mathrm{O}$; (f) DMF.

Table 3 Polymer combinations for ligation experiments

\begin{tabular}{llll}
\hline Ligation type & Hydrophilic & Amphiphilic & Hydrophobic \\
\hline CuAAC & PSar/PSar & PSar/PGlu(OBzl) & PLys(TFA)/PGlu(OBzl) \\
SPAAC & PSar/PSar & PSar/PGlu(OBzl) & PLys(TFA)/PGlu(OBzl) \\
NCL & PSar/PSar & PSar/PLys(TFA) & Not accessible
\end{tabular}

overestimated for amphiphilic CuAAC ligation products, since copper was removed by precipitation in water/MeOH to enable NMR analysis. This was done in order to prove triazole formation (see the ESI $\dagger$ ). In general, precipitation of the coupling reaction is not expected to significantly effect the molecular weight distribution of ligation products, since both individual homopolymers already precipitate under the reported conditions. We want to emphasize here that coupling efficiencies
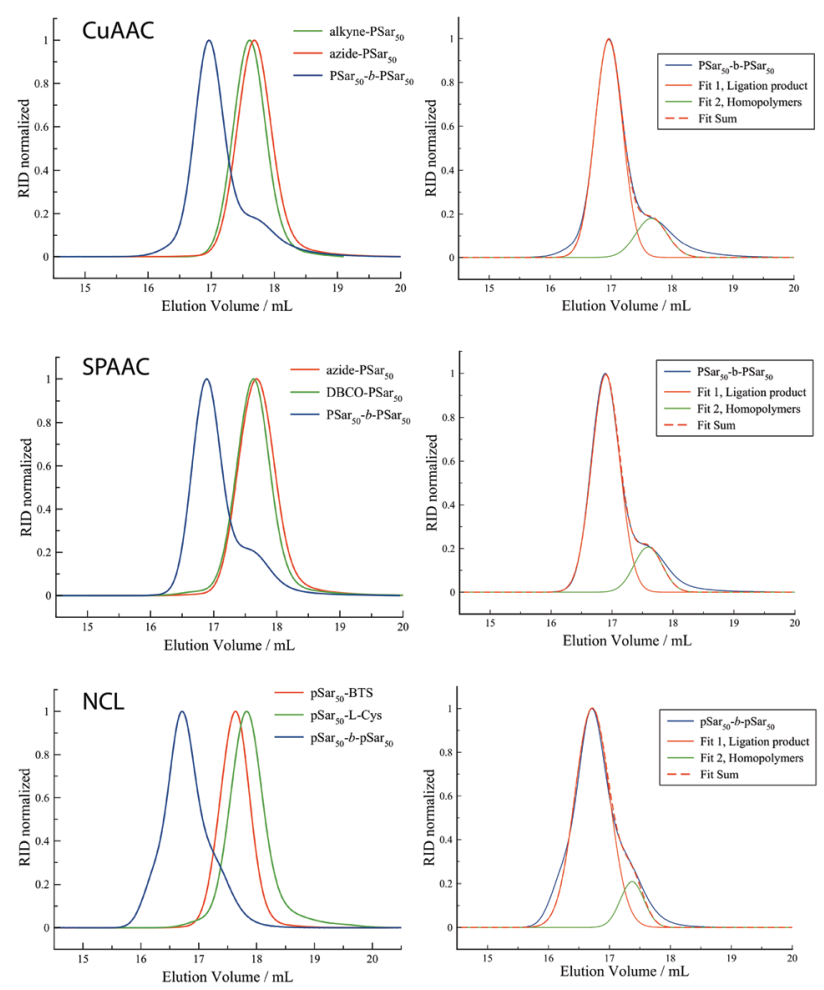

\begin{tabular}{|c|c|c|c|c|c|c|}
\hline \multirow{2}{*}{ Ligation - Polarity } & \multicolumn{2}{|c|}{ Hydrophilic } & \multicolumn{2}{c|}{ Amphiphilic } & \multicolumn{2}{c|}{ Hydrophobic } \\
\hline & short & long & short & long & short & long \\
\hline CuAAC & & & & & & \\
\hline SPAAC & & & & & & \\
\hline NCL & & & & & & \\
\hline
\end{tabular}

Fig. 2 HFIP GPC elugrams of ligation products from CuAAC, SPAAC and NCL $\left(X_{\mathrm{n}}=50\right.$, hydrophilic) and Gauss-fits used to determine efficiencies displayed in the table below.

were primarily determined for better comparability of the different techniques. Nevertheless, these results indicate that block copolypept(o)ide synthesis is feasible with all three presented ligation techniques with good efficiencies.

As expected, in general, ligations between shorter polypeptides are easier to realize than ligations between longer polypeptides/polysarcosine. This is likely due to the increased 
steric demand and the decreased probability of meeting between reactive chain ends. Generally, azide-alkyne coupling reactions gave better results than NCL even if NCL showed very high (up to 88\%) coupling efficiencies for hydrophilic conditions. When the two different types of azide-alkyne coupling reactions are directly compared, SPAAC seems to be slightly superior to CuAAC. Not only are coupling efficiencies slightly better compared to CuAAC, especially for amphiphilic and hydrophobic conditions, but also, for SPAAC, no additional catalyst is necessary. Therefore, the reaction is very simple to conduct and it is not required to work in dry solvents or under inert conditions. When functionalities for click chemistry can be easily introduced into both blocks as shown for homopolymers in this study, SPAAC appears to be the method of choice. On the other hand, chain length determination by ${ }^{1} \mathrm{H}$ NMR is a lot more reliable when neopentylamine ( 9 equivalent protons) or other initiators with clearly detectable signals are used.

In the case of a peptide already bearing an N-terminal Cys residue (synthesized either by SPPS or by biotechnological means), NCL can become the preferred method. However, NCL is optimized for biological applications and is only very easy to conduct in aqueous buffered solutions. In organic solvents, however, the reaction demands working under absolutely dry conditions to avoid hydrolysis of the thioester. If no reducing agent is added, it is also necessary to work under oxygen free conditions to avoid cystine formation, which inhibits the cysteine to further take part in chemical ligation. For the synthesis of amphiphilic conjugates, also mixtures of organic solvents and aqueous buffered solutions are an option.

Nevertheless, it needs to be kept in mind that end group modification might not always be quantitative and is also dependent on the chain length, which further limits this method for block copolymer synthesis.

In this work, the main focus was set on a direct comparison between different ligation techniques and for the purpose of feasible monitoring. Purification of block copolymers, e.g. block copolypept(o)ides, however, can be easily conducted whenever two polymers or peptides, which differ significantly in chemical properties like polarity (solubility) or in size, are used as for example shown by Lecommandoux and coworkers. ${ }^{44}$

Thus, the ligation approach is also a complementary pathway to the sequential ring opening polymerization for the synthesis of amphiphilic block copolypept(o)ides.

\section{Evaluation of cytotoxicity and complement activation of the ligation site}

Since all of the aforementioned methods showed promising results as ligation techniques for block copolymer synthesis, we performed studies on cytotoxicity and complement activation for the resulting short, hydrophilic ligation products $\left(\mathrm{PSar}_{50}+\mathrm{PSar}_{50}\right)$ of all three ligations (L1, L2, L3). Therefore, an MTT assay was performed for block copolymers derived by CuAAC, SPAAC or NCL, which did not indicate significant differences between individual ligation types and also not compared with the reference PSar homopolymer (see the

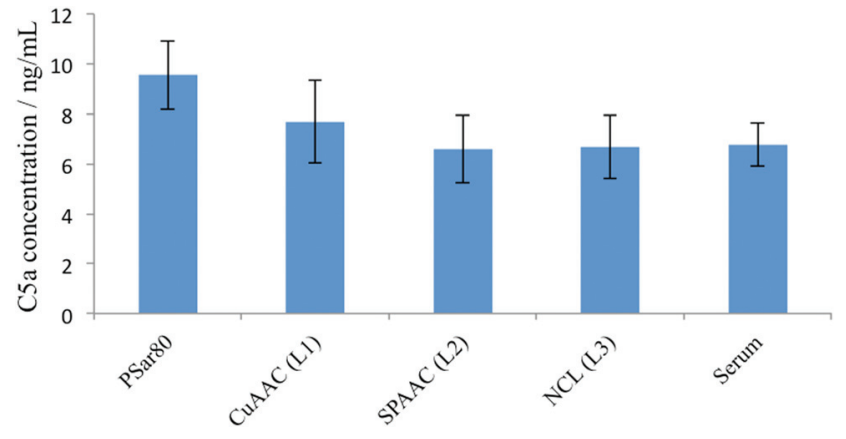

Fig. 3 Concentration of C5a determined by ELISA after incubation of L1 (CUAAC), L2(SPAAC) and L3(NCL) with human serum for $1 \mathrm{~h}$ at $37^{\circ} \mathrm{C}$.

ESI $†$ ). CuAAC and SPAAC ligations result in a triazole moiety as the ligation site as opposed to NCL, where a native amide bond is formed. It could be suspected that these electron deficient aromatic rings, which are not common to the body, would cause activation of the immune system. As an initial test, polymers L1, L2 and L3 were incubated with human serum for $1 \mathrm{~h}$ at $37^{\circ} \mathrm{C}$ and the concentration of human complement factor 5a (C5a) was determined by ELISA (see Fig. 3). Compared to human serum itself, no increased concentration of C5a could be detected.

Hence, these preliminary experiments suggest that the nature of the ligation site neither affects toxicity nor complements activation of these polymers, which is a first crucial requirement for application in nanomedicine. Nevertheless, future research needs to address different types of immune responses apart from complement activation.

\section{NCL with SPPS peptide TCR CP}

For peptides synthesized by SPPS, NCL is a very effective method since end group functionalities can be easily introduced during the cleavage from the resin. Therefore, we used a BTS-modified PSar $_{100}$ for conjugation with a considerably hydrophobic peptide sequence with 9 amino acids bearing a cysteine residue at the N-terminus (CGLRILLKV). This peptide sequence is called the T-cell receptor core peptide (TCR CP) and has shown to inhibit IL-2 production in antigen-stimulated $\mathrm{T}$ cells and thus to suppress inflammation in some animal models of $\mathrm{T}$ cell-mediated disease. ${ }^{43,54}$

PSar $_{124}$-BTS was conjugated to TCR CP in a mixture of $4 \mathrm{M}$ urea buffer/THF 1:1 in the presence of MPAA and TCEP.HCl, using an excess of TCR CP (2 eq.). After purification by precipitation and dialysis, the conjugate was analysed by ${ }^{1} \mathrm{H}$ NMR, DOSY and HFIP GPC.

DOSY data (see Fig. 4) clearly demonstrate covalent attachment to the polymer since the corresponding signals appear as one diffusing species. After the successful synthesis of the conjugate, the HFIP GPC elugram displayed bimodal molecular weight distribution with a second peak at double molecular weight (see Fig. 4). This second peak disappears after treatment with TCEP. $\mathrm{HCl}$ overnight in $\mathrm{H}_{2} \mathrm{O}$. The higher molecular 
A)

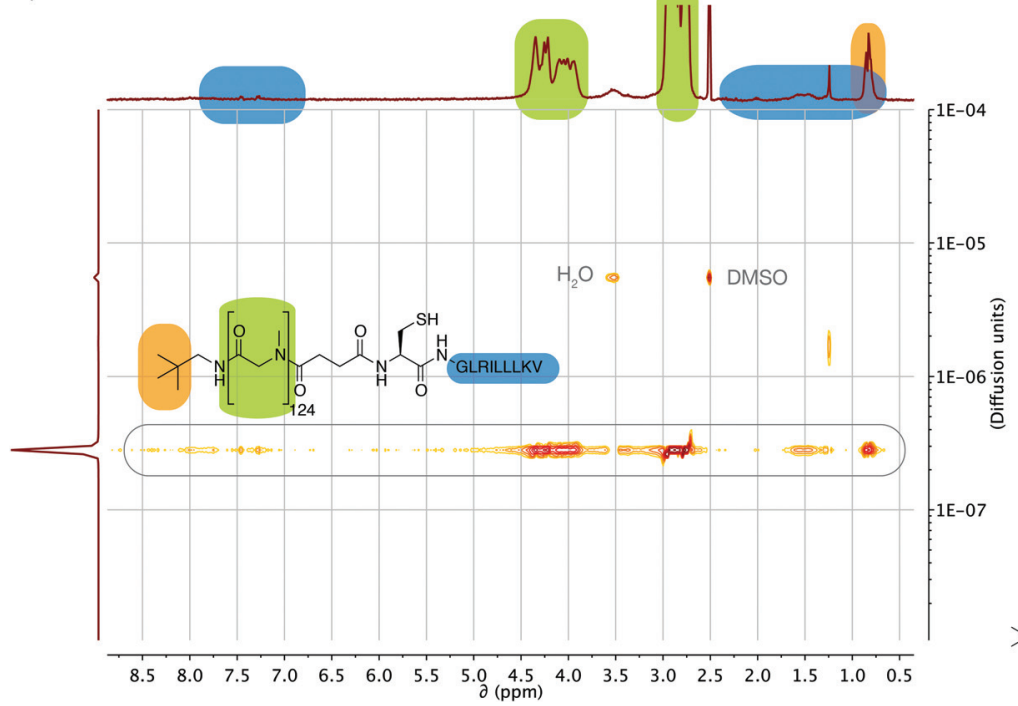

B)

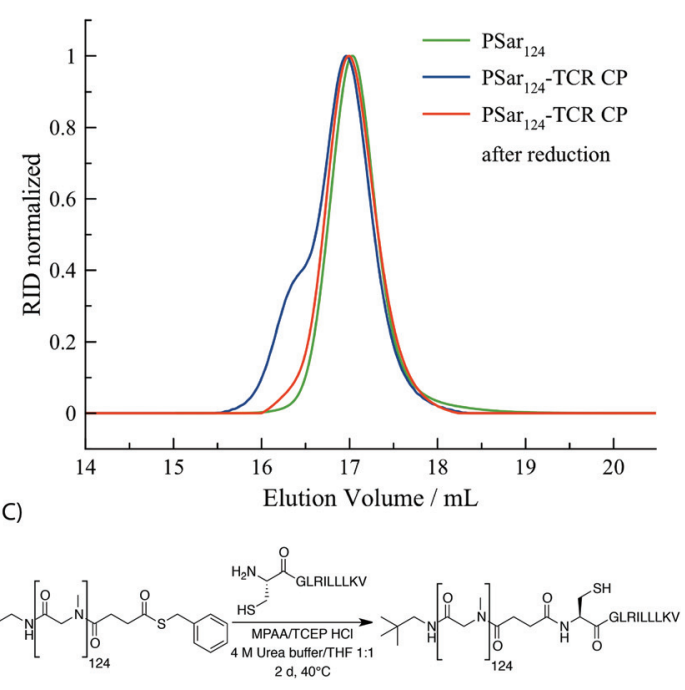

Fig. 4 (A) DOSY ${ }^{1} \mathrm{H}$ NMR of PSar 124 -TCR CP; (B) HFIP GPC elugram before and after conjugation with TCR CP; (C) reaction scheme of conjugation.

weight peak can thus be attributed to dimer formation, which only becomes possible once the free thiol moiety is incorporated into the polymer, further proving the effective coupling of the decapeptide to polysarcosine.

In conclusion, a well-defined conjugate can be obtained under reductive conditions, which can be easily purified by precipitation and dialysis. The conjugate is currently under investigation with respect to inhibition of IL-2 production in different inflammation models.

\section{Conclusions}

We have demonstrated that semitelechelic polypeptides and polypeptoids with low dispersities can be synthesized by using varying functionalized primary amines as initiators or by subsequent peptide coupling at the $\mathrm{N}$-terminus as postpolymerization modification. End group modifications using HOBt/ HBTU/DIPEA coupling at N-termini allowed for the quantitative introduction of cysteine and thioester functionalities to PSar and of cysteine to PLys(TFA). In the latter case, the introduction of the thioester moiety was not possible in a reliable way, due to the occurrence of thioester aminolysis. Furthermore, three different ligation techniques were investigated for block copolymer synthesis. Successful ligation of polymers was analyzed by HFIP GPC and elugrams were fitted by Gaussian distributions to compare individual ligation techniques under different polarity conditions and for two different average chain lengths $\left(X_{\mathrm{n}}=50,100\right)$. SPAAC proved to be most efficient under the given circumstances and straightforward in synthesis. Furthermore, no differences in cytotoxicity or complement activation for ligation products have been detected in preliminary in vitro experiments. Moreover, native chemical ligation has been successfully applied to the synthesis of the
polysarcosine-TCR CP conjugate and stresses the usefulness of this method for coupling with peptides synthesized by SPPS or even natural protein sequences bearing an $\mathrm{N}$-terminal cysteine residue.

\section{Conflict of interest}

The authors declare no competing financial interest.

\section{Acknowledgements}

The authors acknowledge funding from the DFG 1066-1, COMATT, NMFZ Mainz, and Materials Science IN MainZ (MAINZ). K. Klinker would like to thank the HaVo foundation for financial support. P. Heller is a recipient of a DFG fellowship through the Excellence Initiative by the Graduate School of Materials Science in Mainz (GSC 266). Furthermore, the authors would like to thank Alexander Birke for MALDI-TOF measurements.

\section{Notes and references}

1 T. J. Deming, Macromolecules, 1999, 32, 4500-4502.

2 H. Lu and J. Cheng, J. Am. Chem. Soc., 2008, 130, 1256212563.

3 W. Vayaboury, O. Giani, H. Cottet, A. Deratani and F. Schué, Macromol. Rapid Commun., 2004, 25, 1221-1224.

4 I. Conejos-Sánchez, A. Duro-Castano, A. Birke, M. Barz and M. J. Vicent, Polym. Chem., 2013, 4, 3182-3186.

5 H. Peng, J. Ling and Z. Shen, J. Polym. Sci., Part A: Polym. Chem., 2012, 50, 1076-1085. 
6 H. Peng, J. Ling, Y. Zhu, L. You and Z. Shen, J. Polym. Sci., Part A: Polym. Chem., 2012, 50, 3016-3029.

7 R. Webster, E. Didier, P. Harris, N. Siegel, J. Stadler, L. Tilbury, D. Smith and W. E. T. Al, Drug Metab. Dispos., 2007, 35, 9-16.

8 A. Bendele, J. Seely, C. Richey, G. Sennello and G. Shopp, Toxicol. Sci., 1998, 42, 152-157.

9 A. Duro-Castano, I. Conejos-Sánchez and M. Vicent, Polymers, 2014, 6, 515-551.

10 A. Blanazs, S. P. Armes and A. J. Ryan, Macromol. Rapid Commun., 2009, 30, 267-277.

11 A. Carlsen and S. Lecommandoux, Curr. Opin. Colloid Interface Sci., 2009, 14, 329-339.

12 A. Birke, D. Huesmann, A. Kelsch, M. Weilbächer, J. Xie, M. Bros, T. Bopp, C. Becker, K. Landfester and M. Barz, Biomacromolecules, 2014, 15, 548-557.

13 P. Heller, A. Birke, D. Huesmann, B. Weber, K. Fischer, A. Reske-Kunz, M. Bros and M. Barz, Macromol. Biosci., 2014, 14, 1380-1395.

14 P. Heller, N. Mohr, A. Birke, B. Weber, A. Reske-Kunz, M. Bros and M. Barz, Macromol. Biosci., 2015, 15, 63-73.

15 P. Heller, B. Weber, A. Birke and M. Barz, Macromol. Rapid Commun., 2015, 36, 38-44.

16 E. Ostuni, R. G. Chapman, R. E. Holmlin, S. Takayama and G. M. Whitesides, Langmuir, 2001, 17, 5605-5620.

17 J. Sun and R. N. Zuckermann, ACS Nano, 2013, 7, 47154732 .

18 M. Zhou, H. Liu, A. Venkiteshwaran, J. Kilduff, D. G. Anderson, R. Langer and G. Belfort, J. Mater. Chem., 2011, 21, 693.

19 H. Tanisaka, S. Kizaka-Kondoh, A. Makino, S. Tanaka, M. Hiraoka and S. Kimura, Bioconjugate Chem., 2008, 19, 109-117.

20 E. Hara, M. Ueda, C. J. Kim, A. Makino, I. Hara, E. Ozeki and S. Kimura, J. Pept. Sci., 2014, 20, 570-577.

21 E. M. Sletten and C. R. Bertozzi, Angew. Chem., Int. Ed., 2009, 48, 6974-6998.

22 M. D. Best, Biochemistry, 2009, 48, 6571-6584.

23 J. D. Warren, J. S. Miller, S. J. Keding and S. J. Danishefsky, J. Am. Chem. Soc., 2004, 126, 6576-6578.

24 M. Köhn, J. Pept. Sci., 2009, 15, 393-397.

25 C. P. R. Hackenberger and D. Schwarzer, Angew. Chem., Int. Ed., 2008, 47, 10030-10074.

26 H. C. Kolb, M. G. Finn and K. B. Sharpless, Angew. Chem., Int. Ed., 2001, 40, 2004-2021.

27 C. W. Tornøe, C. Christensen and M. Meldal, J. Org. Chem., 2002, 67, 3057-3064.

28 R. Huisgen, Angew. Chem., Int. Ed. Engl., 1963, 2, 565-598.

29 R. Huisgen, Angew. Chem., Int. Ed. Engl., 1963, 2, 633-645.
30 N. J. Agard, J. A. Prescher and C. R. Bertozzi, J. Am. Chem. Soc., 2004, 126, 15046-15047.

31 G. Wittig and A. Krebs, Chem. Ber., 1961, 94, 3260-3275.

32 H. Stöckmann, A. A. Neves, S. Stairs, H. Ireland-Zecchini, K. M. Brindle and F. J. Leeper, Chem. Sci., 2011, 2, 932936.

33 H. Li, R. Aneja and I. Chaiken, Molecules, 2013, 18, 97979817.

34 G. K. Such, A. P. R. Johnston, K. Liang and F. Caruso, Prog. Polym. Sci., 2012, 37, 985-1003.

35 J.-F. Lutz, Angew. Chem., Int. Ed., 2007, 46, 1018-1025.

36 B. J. A. Opsteen, L. Ayres, P. J. C. M. Van Hest and M. M. Volume, Mater. Matters, 2011, 3, 1-6.

37 P. K. Avti, D. Maysinger and A. Kakkar, Molecules, 2013, 18, 9531-9549.

38 M. Schnolzer and S. Kent, Science, 1992, 256, 221-225.

39 P. Dawson, T. Muir, I. Clark-Lewis and S. Kent, Science, 1994, 266, 776-779.

40 T. W. Muir, Annu. Rev. Biochem., 2003, 72, 249-289.

41 M. Dittmann, J. Sauermann, R. Seidel, W. Zimmermann and M. Engelhard, J. Pept. Sci., 2010, 16, 558-562.

42 M. Dittmann, M. Sadek, R. Seidel and M. Engelhard, J. Pept. Sci., 2012, 18, 312-316.

43 N. Manolios, S. Collier, J. Taylor, J. Pollard, L. C. Harrison and V. Bender, Nat. Med., 1997, 3, 84-88.

44 W. Agut, R. Agnaou, S. Lecommandoux and D. Taton, Macromol. Rapid Commun., 2008, 29, 1147-1155.

45 C. Fetsch and R. Luxenhofer, Polymers, 2013, 5, 112-127.

46 N. M. B. Smeets, P. L. J. van der Weide, J. Meuldijk, J. A. J. M. Vekemans and L. A. Hulshof, Org. Process Res. Dev., 2005, 9, 757-763.

47 D. a. Stetsenko and M. J. Gait, J. Org. Chem., 2000, 65, 4900-4908.

48 D. Huesmann, A. Birke, K. Klinker, S. Türk, H. J. Räder and M. Barz, Macromolecules, 2014, 47, 928-936.

49 F. Fuchs, Ber. Dtsch. Chem. Ges. A B Ser., 1922, 55, 29432943.

50 A. C. Farthing and R. J. W. Reynolds, Nature, 1950, 165, 647-647.

51 H. R. Kricheldorf, $\alpha$-Aminoacid-N-Carboxy-Anhydrides and Related Heterocycles: Syntheses, Properties, Peptide Synthesis, Polymerization, Springer, Berlin-Heidelberg-New York, 1987.

52 M. S. Cherevin, T. G. Gulevich, L. A. Popova, Z. P. Zubreichuk and V. A. Knizhnikov, Russ. J. Org. Chem., 2007, 43, 1427-1431.

53 C. Fetsch, A. Grossmann, L. Holz, J. F. Nawroth and R. Luxenhofer, Macromolecules, 2011, 44, 6746-6758.

54 X. M. Wang, J. T. Djordjevic, V. Bender and N. Manolios, Cell Immunol., 2002, 215, 12-19. 